\title{
Exegesis of Romans 13:1-7 and its appropriation to the new dispensation of the Second Republic of Zimbabwe
}

\begin{tabular}{|c|c|}
\hline $\begin{array}{l}\text { Author: } \\
\text { Ishanesu S. Gus }\end{array}$ & $a^{1,2}$ \\
\hline $\begin{array}{l}\text { Affiliation: } \\
{ }^{1} \text { Department of } \\
\text { Classics and Phi } \\
\text { of Arts, Univers } \\
\text { Harare, Zimbab }\end{array}$ & $\begin{array}{l}\text { Religious Studies, } \\
\text { osophy, Faculty } \\
\text { ty of Zimbabwe, } \\
\text { ve }\end{array}$ \\
\hline $\begin{array}{l}{ }^{2} \text { Department of } \\
\text { and Related Lite } \\
\text { Theology and R } \\
\text { of Pretoria, Pre }\end{array}$ & $\begin{array}{l}\text { New Testament } \\
\text { rature, Faculty of } \\
\text { ligion, University } \\
\text { oria, South Africa }\end{array}$ \\
\hline $\begin{array}{l}\text { Research Proje } \\
\text { Project Leader: } \\
\text { Project Numbe }\end{array}$ & $\begin{array}{l}\text { t Registration: } \\
\text { E. Van Eck } \\
: 2400030\end{array}$ \\
\hline $\begin{array}{l}\text { Description: } \\
\text { Ishanesu S. Gus } \\
\text { in the research } \\
\text { 'Hermeneutics } \\
\text { directed by Pro } \\
\text { Eck, Departmen } \\
\text { Testament Stud } \\
\text { Theology and R } \\
\text { of Pretoria }\end{array}$ & $\begin{array}{l}\text { a is participating } \\
\text { oroject, } \\
\text { nd Exegesis', } \\
\text { Dr Ernest van } \\
\text { of New } \\
\text { es, Faculty of } \\
\text { ligion, University }\end{array}$ \\
\hline $\begin{array}{l}\text { Corresponding } \\
\text { Ishanesu S. Gus } \\
\text { ishegusha2@gn }\end{array}$ & $\begin{array}{l}\text { author: } \\
\text { na, } \\
\text { lail.com }\end{array}$ \\
\hline $\begin{array}{l}\text { Dates: } \\
\text { Received: } 16 \mathrm{Ap} \\
\text { Accepted: } 12 \mathrm{AL} \\
\text { Published: } 27 \mathrm{O}\end{array}$ & $\begin{array}{l}\text { r. } 2020 \\
\text { g. } 2020 \\
\text { ct. } 2020\end{array}$ \\
\hline $\begin{array}{l}\text { How to cite this } \\
\text { Gusha, I.S., } 202 \\
\text { of Romans } 13: 1 \\
\text { appropriation tc } \\
\text { dispensation of } \\
\text { Republic of Zim } \\
\text { HTS Teologiese } \\
\text { Theological Stuc } \\
\text { https://doi.org/ } \\
\text { v76i4.6041 }\end{array}$ & $\begin{array}{l}\text { article: } \\
\text {, 'Exegesis } \\
-7 \text { and its } \\
\text { the new } \\
\text { the Second } \\
\text { abwe', } \\
\text { tudies/ } \\
\text { lies } 76(4) \text {, a6041. } \\
10.4102 / \text { hts. }\end{array}$ \\
\hline $\begin{array}{l}\text { Copyright: } \\
\text { (C) 2020. The Au } \\
\text { AOSIS. This wor } \\
\text { under the Creat } \\
\text { Attribution Lice }\end{array}$ & $\begin{array}{l}\text { thors. Licensee: } \\
\text { is licensed } \\
\text { ve Commons } \\
\text { se. }\end{array}$ \\
\hline Read online: & \\
\hline 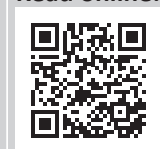 & $\begin{array}{l}\text { Scan this QR } \\
\text { code with your } \\
\text { smart phone or } \\
\text { mobile device } \\
\text { to read online. }\end{array}$ \\
\hline
\end{tabular}

The interpretation and appropriation of Romans 13:1-7 have been a challenge for generations because this text confuses Christians as to how they should relate and participate in the politics of the day. This article interprets the text in its historical and literary context before appropriating it to the Second Republic of Zimbabwe. The conclusion reached is that the text does not directly speak to church-state relations but rather should be understood in its context in Paul's time. Appropriating the text to the Second Republic requires us to delineate whether the governing authorities of the Second Republic are doing the will of God or whether they are terrorising people into obedience. The article concludes that the text does not forbid people from resisting illegitimate and brutal governments and does not demand passive citizenship.

Contribution: The article is an interpretation and appropriation of Romans 13:1-7 to the Second Republic of Zimbabwe. Appropriating the text to the Second Republic requires one to delineate whether the governing authorities are doing the will of God or not. It is within the scope of this theological journal that issues of church-state relationships and theological reflection should be addressed, hence this article fits well within this scope.

Keywords: Second Republic; Exegesis; Zimbabwe; Mnangagwa; Mugabe; Romans; Government; Authorities.

\section{Introduction}

The subject of church-state relations has been debated over a long period of time, and even now scholars are still at loggerheads. Romans 13:1-7 has been one of the texts at the centre of the debate. O'Neill (1975) argues that:

$[T]$ hese seven verses have caused more unhappiness and misery in the Christian West and East than any other seven verses in the New Testament by the license they have given to tyrants. (p. 209)

Today, there are divergent views on the interpretation and appropriation of the text. Those from democratic, stable and responsible governments tend to understand the text differently from those who live under autocratic, brutal and irresponsible governments. The aim of this article is to exegete Romans 13:1-7 and examine how it is appropriate to the new dispensation of the Second Republic of Zimbabwe. However, before exegeting the text, the background of the Second Republic of Zimbabwe will be given.

\section{The historical background of the Second Republic}

The phrase 'Second Republic' implies that there was a First Republic. Therefore, as one interrogates the historical background of the Second Republic, the First Republic becomes part of that background. The two phrases, 'First Republic' and 'Second Republic', are used about the nation of Zimbabwe and refer to two different time frames of the country's politics. Garlake claims that the name 'Zimbabwe' is derived from dzimba-hwe, which means 'venerated houses' in the Zezuru dialect of Shona, and it is usually applied to the houses or graves of chiefs and translated as 'great houses of stone' or 'stone buildings' (Garlake 1973:13).

\section{The First Republic}

Zimbabwe attained her independence in 1980 after almost two decades of a war of liberation. This was the birth of the First Republic under the leadership of Robert Mugabe, who was the executive

Note: Special Collection entitled Africa Platform for NT Scholars, sub-edited by Ernest van Eck (UP). 
prime minister. Gusha mentions that in his victory speech, 'Mugabe introduced the themes of peace and stability as key and priority for nation-building' (Gusha 2019:4). When he named his first 23 cabinet ministers, Emmerson Dambudzo Mnangagwa was appointed to the post of minister of State in the prime minister's office. Since that appointment, Mnangagwa occupied the following positions in the First Republic until his dismissal in 2017: minister of Justice, Legal and Parliamentary Affairs; minister of Finance; minister of Rural Housing and Social Amenities; minister of Defence; Speaker of Parliament; and vice president. Therefore, Mnangagwa played a vital role in the First Republic for 37 years.

The regime of the First Republic (1980-2017) had successes and failures. The First Republic scored some successes in education, health, food security and national and regional security. Most of these successes were achieved in the first 10 years, and in the last 27 years, things deteriorated across all facets of the economy, politics and society. Brett argues that 'most African states acquired democratic constitutions at independence, but soon fell prey to oligarchical rulers or military dictators' (Brett 2006:1). This seemed to be the situation with the Zimbabwean political narrative. Slowly, such states crumble because of corruption, mismanagement and conflicts resulting from poverty and unequal distribution of resources. Though the First Republic made significant progress in nation building during the transition from minority rule to majority rule, their 37-year history is permeated with a negative narrative. This narrative has been characterised by conflict, nepotism, corruption, pre- and post-election violence, ethnic and political intolerance, state capture, abductions, massacres, dictatorship, mismanagement, hate speech, election manipulation and fragmentation. Chitiyo and Kibble (2014:9) note that 'Zimbabwe was ranked 157 out of 177 in the 2013 Transparency International Corruption Perception Index'. This demonstrates how things have deteriorated in the First Republic. This is the Zimbabwean political and economic script that necessitated the ushering in of the Second Republic.

\section{The rise of the Second Republic}

The Second Republic was born in 2017 after a period of serious factional tensions within the ruling Zimbabwe African National Union-Patriotic Front (ZANU-PF) party that were threatening the security of the country. According to Noyes, 'President Emmerson Mnangagwa came to office on the back of a military coup in November 2017, replacing President Mugabe who was in power for thirty-seven years' (Noyes 2020:III). The future seemed promising for the majority of Zimbabweans, as the thinking was that Mugabe was the man behind all the problems facing the country (Zimbabwe Human Rights NGO Forum 2019):

The Second Republic of Mnangagwa and the 'open for business' mantra seemed to be highly encouraging at first, but, with the elections looming in mid-2018, it proved illusory as hard economic decisions were avoided. (p. 4)

People began to ask questions about what is 'new' in the Second Republic, especially when the successor of Mugabe had been his beloved disciple since the liberation war. The argument is that what happened in November 2017 was the replacement of the old dispensation with the new old dispensation. This explains why even his choice of cabinet ministers returned the old horses, with some few provisions for the coup architects from the military. How could Zimbabweans have been so naïve as to expect reasonable change from someone who had been, for 37 years, part of the very system that needed to be changed? Costa Nkomo observed correctly when he wrote that 'Emmerson Mnangagwa is feeding on his predecessor's political script' (Nkomo 2019:3).

The question then is, what went wrong with Mnangagwa's administration in the Second Republic? Noyes' response to this question is that 'there is a wide gap between the government's reform rhetoric and the reality on the ground' (Noyes 2020:VIII). How is that justified? Noyes (2020) further argues that:

Mnangagwa is in many ways governing in a more repressive manner than Mugabe. Since he came into power more than twenty people were killed and more than one thousand arrested by security forces. (p. ix)

The use of the military to terrorise people is on the rise. Violence against civilians has not changed, and there seems to be the same trajectory between the First and Second Republics. The Second Republic is still singing the same litany of the First Republic attacks, sexual violence, abductions and forced disappearances of civilians. The Zimbabwe Human Rights NGO Forum (2019:4) report argues that 'Zimbabwe is more deeply divided now than at any time in its history'. The culture of violence during elections that characterised the First Republic has not changed at all. According to Bratton and Masunungure (2018:1), 'Zimbabwe's July 30, 2018 elections seemed to promise relief from a traumatic political past, but a change was not to be'. What appears to be a peaceful and calm environment towards elections was marred by post-election violence that resulted in causalities of six civilians. The election playing field remained uneven in the following ways: the Zimbabwe Electoral Commission remained biased towards the ruling party; the state media remained partisan in terms of covering ZANU-PF rallies; the voter roll remained a sacred text not to be shared with other political parties; and security forces intimidated the civilians. The delay in releasing the presidential results sent people into the streets to protest, and the national army was unleashed on the protesters, resulting in the death of six people on 01 August 2018. Whilst the streets were still flowing with the blood of these six people, the following day, the Zimbabwe Electoral Commission declared Mnangagwa the winner with $50.8 \%$ of the total votes, whilst his closest rival, Nelson Chamisa, was given 44.3\%. Murisa argues that 'whereas protesters were either arrested or beaten up under Mugabe. We do not recall a time when seven were shot in one incident just after the elections' (Murisa 2019:25). In January 2019, 17 more people were killed in fuel hike protests. Economically, inflation continues to rise 
against people's meagre salaries, resulting in deteriorating living conditions. The woes of the people are far from over in the Second Republic; hence people are beginning to question the legitimacy and sanctity of the New Dispensation. According to the constitution of Zimbabwe, especially in the preamble, there is an acknowledgement of the 'supremacy of the Almighty God, in whose hands the future of the country lies' (Constitution of Zimbabwe 2013:15). The constitution does not, however, state the identity of this almighty God. Furthermore, the founding values and principles of the constitution acknowledge diversity in terms of culture, religions and traditional values (Constitution of Zimbabwe 2013:15). Therefore, Zimbabwe is a pluralistic country where the rights of all people are preserved regardless of ethnic, cultural and religious background. However, in terms of religious demography, Christians are the majority. According to Robert Matikiti, 'the church is the largest constituency in Zimbabwe, it is also closest to the people and has a credible voice' (Matikiti 2009). According to the International Religious Freedom Report (IRFR) of 2018 (Boehme ed.) the religions demography of Zimbabwe is as follows: Christians, 86\%; African Traditional Religion, 2\%; Islam, 1\%; and non-religious people, 11\% (IRFR 2018). This explains why Christianity dominates the public space in Zimbabwe. School children recite the Lord's Prayer at the assembly, even at government schools. Parliamentarians, ministers and the president are sworn into the office holding the Bible. Chaplains to serve in the army, police, prisons, air force and central intelligence office are drawn from the Christian religion. In 2019, the president (Emmerson Mnangagwa) appointed a 26-member advisory council, and only two (Dr Shingi Munyeza and Dr Kenneth Mtata) were appointed to represent the Faith-Based Organization (http://www.theopc.gov.zw/index.php/362president-sets-up-advisory-council). Both of them came from the Christian fraternity. Dr Kenneth Mtata, however, rejected the appointment, and this shows that Christianity is a dominant religion in Zimbabwe. This is the reason why the Bible is used by the Second Dispensation in political discourses to legitimise it, and it is in this context that Romans 13:1-7 is examined. Though Zimbabwe is not a Christian state, there is a bias towards Christianity by state leaders because it appeals to the masses.

\section{The historical context of Romans 13:1-7}

Understanding the historical context of a text is key in exegesis, as 'a text without a context is a pretext' (Gorman 2009:69). We need to exegete Romans 13:1-7 in light of the historical context of the Roman Empire in the time of Paul, and this will help in avoiding misinterpretation of the text. The major challenge today is that when Paul talks of submitting to the governing authorities, what comes to our mind is our governing system, which may be completely different from that in Paul's time. Such an understanding of the historical context helps us in the appropriation of the text. Paul's ministry was exercised during the period when the Roman Empire was the superpower of the day; this is the socio-economic and political context that needs to be understood as part of the exegesis. M. G. Neufeld argues that 'there are three main hypotheses for the historical and social context in Rome that formed the background to Paul's argument in 13:1-7' (Neufeld 1994:94). The first hypothesis was championed by Kasemann. He (Kasemann 1980) argues that:

Paul's exhortation in chapter 12 is against 'enthusiasm' and that this carries over into chapter 13, where Paul is resisting the attitude which in virtue of heavenly citizenship views earthly authorities with indifference or content. (p. 351)

The issue of temporal and permanent powers had been at the centre of theological reflections amongst the church fathers, especially one that is superior to the other. This is what Kasemann sees as the issue that Paul is dealing with in Romans 12 and 13. However, this hypothesis is dismissed by Neufeld (1994), who refutes it:

$[T]$ he problem with this view is that 'enthusiasm' is not apparent within the argument itself. Caution must be used with Kasemann's conclusions; he tends to draw questionable parallels between the situation in the Corinthian community and the one in Rome. (p. 94)

The next hypothesis was championed by J.I.H. McDonald when he looked at the historical context from the perspective of taxation. McDonald argues that 'Paul is thus warning his readers in 13:1-7 against joining a selfish opposition to excessive taxation, which is a form of conforming to "this world"' (McDonald 1989:546). This hypothesis has some internal evidence from the text itself and is supported by famous historians such as Suetonius and Tacitus. What is also important to consider is the Roman taxation system because there is an appeal to pay taxes. Though they were many types of taxes, two ( According to Esler (2003):

popo $\varsigma$ was known as the provincial tax. It was a levy placed on people and land that was compelled on everyone in the empire, except for Roman citizens living in Roman colonies and the $\tau \varepsilon \lambda o \varsigma$ on the other hand, was a levy on income, goods, and services. (p. 332)

So, when Paul urge Christians to pay their taxes, which taxes is he referring to? Is he referring to both or one of them? What would be the implications of not paying taxes? More of these issues will be discussed later. What is important is that Paul is writing during the period when the Roman government was in control of the vast empire, and the governing system was quite different from the contemporary democratic systems. Such background helps in analysing Paul in his context.

The third hypothesis is famously attributed to Marcus Borg. He (Borg) argues that 'Paul's concern in Romans 13:1-7 is that Jewish Christians refrain from joining a revolutionary, nationalistic movement which might undermine the unity of Jews and Gentiles in the Roman Church' (Culpepper 1974:457). It seemed as if the Jewish Christians in Rome were 
in contact with the Jews in Palestine and were in agreement in terms of anti-Roman imperial policy. This had led to the expulsion of Jews in Rome around AD 49, and Jewish Christians such as Priscilla and Aquila were also victims of this event. Paul did not want this to happen again to the group of Christians, which was growing slowly. In chapters 1-11, Paul had managed to argue for the equality of Jews and Gentiles before God, and now this chapter was written to this mixed group. Brenda (2011) argues that:

$[B] y$ this time, the Christians in Rome were an eclectic group. There were Jews who had endured temporary expulsion by the Roman government, there were slaves who were in danger of execution if their masters were killed, and there were citizens subject to the exploits of tax collectors. (n.p.)

Therefore, Paul is writing this letter in the context of years of palace skirmishes involving murder, adultery and all forms of injustice. Regardless of all these palace power wrangles, Christians were still safe from systematic persecution. Systematic persecution was to come later, with the reign of Emperor Nero. Wolfgang argues that 'those who are familiar with Paul's missionary carrier know that he had found the Roman Empire a help in his work' (Forell 1975:26). Thiselton further argues that 'in Paul's life the authority of Rome had saved him from the arbitrary persecutions of Jews, the attacks of bandits, and much else' (Thiselton 2016:230). The empire had managed to foster peace in the entire ancient Near East, to the extent that people would travel to other places with minimum danger. Infrastructural development in terms of state-of-the-art roads had made travelling easy, and this helped Paul to travel to different places whilst propagating the gospel. The letter seemed to have been written in the earlier years of Nero's reign, when he had promised a different and better peace as compared to that of Augustus Caesar's Pax Romana. During such a peace, the government would refrain from the use of excessive force in the governing of the empire. Maybe such stability led Paul to have a high regard of the government of the day. As a Roman citizen, he enjoyed many privileges, such as his right to appeal to Caesar. Were these benefits and privileges in the background of Paul's appeal to submit to governing authorities? However, all these promises would be abandoned a few years later, as Nero blamed Christians for the fire he set on the palace to justify his building project of a new palace. This is a historical reconstruction exercise that cannot be solely relied on because there are no explicit scriptural references to back it.

\section{Literary context}

The literary context of Romans 13:1-7 is contested in Romans scholarship. Two major schools of thought emerge from this debate, that is, those who see the pericope as interpolation and those who see the pericope as neatly connected to the body of the letter. Those in support of the first view raise the following arguments: firstly, as Morris (1988) proffers:

[S]ince it forms a unit without formal grammatical connection to what precedes or follows and since verse 8 would follow quite naturally in 12:21, some see it as an interpolation into a letter that originally lacked it. (p. 457)
Secondly, in furthering the issue of formal grammatical connection, scholars such as Dunn raise the issue of the abruptness of the transition marked by the lack of conjunction or a joining particle and the switch to third person' (Dunn 1988:759) as proof of the theory of interpolation. Thirdly, those who follow this school of thought also raise a theological argument in support of their interpolation theory. The lack of explicit Christological and eschatological themes in the passage is considered non-Pauline and the work of the redactor (Longenecker 2016:951). How convincing are the reasons raised by this school of thought? Firstly, the theory of interpolation is difficult to prove because this literary style is common in the New Testament. Intercalation is one such common usage, especially in the Gospel of Mark (Kusio 2015:265). Even in 2 Corinthians, Paul is fond of using such digressions in his writings. It is also not factual that Paul always incorporates Christological and eschatological themes in all his writings.

There are several objections to this theory. Dunn argues that there is no evidence even from that subject of the text that justifies it as an interpolation (Dunn 1988:759). Esler, Isaak and Horrell agree with Dunn. For example, Isaak (2003) argues that:

[A] close reading of Romans 13:1-7 begins by noting that this text is part of, and should not be separated from a larger section in Paul's letter to the Romans (12:1-13:14). (p. 35)

For example, Romans 12:21 concludes with the following words: 'do not be overcome by evil, but overcome evil with good'. The word 'good' appears again three times in Romans 3:3-4. Importantly, Esler argues that '12:31 leads naturally into a treatment of co-operation with tax gathering authorities who were renowned for their evil' (Esler 2003:331). It is not sufficient to judge the flow of the story by observing literary styles; thematic and theological issues are also of importance. The flow of the story is as follows: Romans 12:121 talks about Christian living - how Christians should live in harmony with one another and not take vengeance. Then, Romans 13:1-7 instructs Christians on how to conduct themselves in the public sphere. In other words, Christians in Rome are being instructed on how to be good citizens. Then, Romans 13:8-10 concludes with the love of one's neighbour. Horrell concludes that 'the theme of peaceable, nonretaliatory conduct became established in early Christian paraenesis and Rom 13:1-7 forms a crucial case study of how this should work about the state authorities' (Horrell 2003:93). From Romans 1:18 Paul had embarked on the project of reconfiguring the boundaries of Christians in a multicultural society, where he is instructing Christians in Rome on how to cope with hostility in such a political environment.

\section{Formal analysis}

Interpreting passages involves indicating how a specific passage is internally organised. Outlining the structure of the passage is part of the interpretive exercise, and it is integral for this article. The outline is then followed by the defence justifying it. 


\section{Outline}

The Christian and governing authorities (Rm 13:1-7).

Firstly, government's legitimate authority and the Christian's response (Rm 13):

1. Let everyone be subject to the governing authorities (v. 1a).

2. For there is no authority except from God (v. 1b).

3. All authorities that exist are appointed by God (v. 1c).

4. Resisting authority is resisting the ordinance of God (v. 2a).

5. Resisting authority is bringing judgment to oneself (v. 2b).

Secondly, the role of government is to punish evildoers ( $\mathrm{Rm} 13)$ :

1. For rulers are not a terror to good works, but to evil (v. 3a).

2. The way to be free from the fear of authorities is to do what is right (v. 3b, c).

3. The authorities are God's servants for good (v. 4a).

4. The authorities do not bear the sword in vain (v. $4 \mathrm{~b}$ ).

5. The authorities are agents of God's wrath and punishment on evildoers (v. 4c).

Thirdly, the Christian's responsibility towards government (Rm 13):

1. Therefore, you must be subject to the authorities (v. 5a).

2. As a matter of conscience (v. 5b).

3. Pay taxes (v. 6).

4. Render to all what is due to them: tax, custom, fear and honour (v. 7).

The text can be divided into three sections. The first section has to do with the government's legitimate authority and the Christian's response. Verse 1a functions as the main thesis statement of the whole pericope. Then the remaining part of Verse 1 is a theological argument, supporting the main thesis statement in Verse 1. Verse 2a then functions as a sub-thesis statement explaining the role of the government as God's arm. The role of the government, then, is to maintain peace and order as well as punishing evil. The duty of citizens, therefore, is to be obedient and behave well. The third section narrows down the responsibilities of the citizens. Verse $3 a$ again functions as the second subthesis, emphasising the issue of being subject to the authorities. Yes, people have been told that they must submit themselves to the governing authorities, but the question is how? Verses 6 and 7 then answer the question thus: by paying required taxes and rendering to all what is owed to them.

\section{Detailed analysis}

In this section, the text is analysed following the above outline. Marshall argues that 'Rom 13:1-7 remains a conundrum, an aporia through which standard exegetical techniques will not cut' (Marshall 2008:162). Is Marshall correct about his view of the text? A closer reading and detailed analysis of the text reveals that there are no internal and irresolvable conflicts. Verse 1a opens with instruction in the imperative form, По̃ $\sigma \alpha$

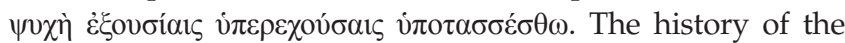
transmission of this text shows that there were no significant changes or omissions. For example, Longenecker notes that

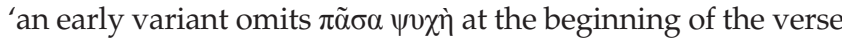

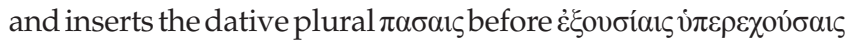

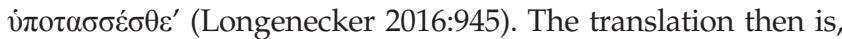
'[b]e subject to all the governing authority'. The variant should have entered the Greek text in the 3rd century. For Longenecker, there is nothing theologically significant about the variant; it is just 'an attempt to expand the significance of the phrase

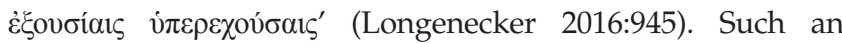
explanation accommodates all governing authorities instead

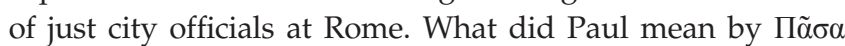

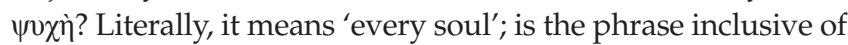
all people, Christians and non-Christians, or is it explicitly referring to Christians? Was he referring to Christians in Rome only or Christians in general? Longenecker and Cranfield

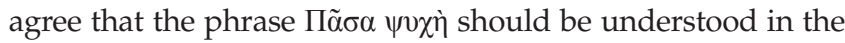
Roman context and that it refers to Christians in Rome (Longenecker 2016:945). There is no reason for objecting to Longenecker and Cranfield's argument. Another contested word is $\dot{\varepsilon} \xi o v \sigma i \alpha$. The dative plural feminine form of the word means 'powers' or 'authorities'. What was in Paul's mind when he used this word? Scholarly views differ in response to this question, and there are two main views. The first view argues that Paul used this term to refer to spiritual or angelic beings. Cranfield is one such scholar who is cited by Longenecker, arguing that 'in every other place in the Pauline epistles where $\dot{\varepsilon} \xi$ ov ${ }^{\prime} \alpha$ occurs in the plural or the plural used singular with $\pi \tilde{\alpha} \sigma \alpha$, it signifies invisible angelic powers' (Longenecker 2016:957). Cranfield, therefore, is arguing based on Paul's common usage of the word, but such a line of argument is deceptive in the presence of minority cases. Moo and Dunn disagree with Cranfield. They both argue that the term $\dot{\varepsilon} \xi o v \sigma i \alpha 1 \varsigma$ refers to human governing authorities, not spiritual beings. This article concurs with them because their argument is more convincing than that of Cranfield. For example, Moo (1996) postulates that:

$[A] \mathrm{s}$ parallel terms in this context, the authorities occupy positions in secular government. Paul qualifies them as 'governing' to indicate that they are in positions of superiority over the believers he is addressing. (p. 796)

There is nothing concrete in the usage of $\dot{\varepsilon} \xi$ ovoíars that suggests angelic powers.

In verses $1 b$ and $1 c$, Paul makes a theological defence for his proposition. Christians should be subject to governing authorities because, firstly, there is only one authority, which is God, and secondly, all other earthly authorities are appointed by God. Textual critics also noticed a slight variation in the transmission of the part of the verse. The interest is in the prepositional phrase viò $\theta \varepsilon o v$, which means 'by God'. The other variant replaces the preposition vimò with $\dot{\alpha} \pi$ o before the genitive $\theta \varepsilon$ oṽ. The resultant translation then 
becomes 'from God' instead of 'by God'. This variant is attested to in the manuscripts that fall into category II. Longenecker argues that textual support for the variant is too weak to be accepted and that it was probably done to effect a linguistic improvement that would more ably signify "that which God has established"' (Longenecker 2016:946).

Paul here made a theological proposition that is difficult to accept. Are autocratic and cruel governments instituted by God? Can we take governments through military coup as instituted by God, given the ancient Latin adage vox populi, vox $\mathrm{Dei}$ [the voice of the people is the voice of God]? What about those who rig elections? Does God delegate his authority to such governments? If so, what type of authority and to what purpose? Forell argues that 'there is more to this passage than Paul's personal opinion about the government of his time' (Forell 1975:26). Paul is making a theological statement, and here is his theological equation: the world belongs to God; God uses human beings to govern his world. Therefore, human leadership is there to accomplish God's purpose. Paul is convinced that governing authorities are not a human device but divine in nature. Maybe Paul is influenced by his Jewish background, where leaders were appointed by God. The problem with Paul is that he does not distinguish between legitimate and illegitimate authority, which is a reality. Saul in the Old Testament is a case study of legitimate and later illegitimate authority. So, at what point will the leader remain legitimate in God's eyes? Can Paul's instruction be taken as a blueprint for political theology? Moulder's (2017) answer is no:

Romans 13 is not an exercise in political theology. It is an attempt to deal with a pastoral problem which existed in the Roman Church at the time when Paul wrote his letter. (p. 17)

This instruction, therefore, should be understood in its original context and not as a prescription to the generality of Christians. Morris concludes that 'he (Paul) does not face, let alone resolve, the problem of when it is right to rebel against unjust tyranny' (Morris 1988:459).

In Verse 2, there are no significant textual issues to discuss. Paul expands his theological argument by stating that resisting the authorities is resisting God because these rulers have delegated authority. Such a negative response to the governing authorities evokes judgment. What does Paul mean by the word 'judgment' in this context? Moo proffers that 'it is better to understand the judgment here to be the eschatological judgment of God' (Moo 1996:799). Dunn argues that 'to receive judgment is Semitic and simply means, to be condemned' (Dunn 1988:762). This study concurs with Dunn's position because the word 'judgment' should be understood in its literary context. The word should be connected to what follows in Verse 4; it should be understood in the context of the words 'sword' and 'retribution on the wrongdoer', which are not used in any eschatological sense.

In section 2, verses 3-4, Paul raises another controversial issue: the role of government in punishing evildoers. The propositions he raises are not in tandem with what people have experienced throughout history. For example, 'rulers are not a terror to good works, but to evil', 'rulers are God's servants for the good of the people' (Rm 13:3). Throughout the history of humanity, these propositions have proven to be partially true. Probably many Americans will agree with the propositions, but that cannot be true for Zimbabweans, where people have been killed for exercising their democratic rights by being affiliated to the opposition parties. Even in the Old Testament, there are cases of kings who punished their subjects for unjust reasons: David and Uriah, and Ahab and Naboth. What about Hitler and Mussolini? What about Idi Amin, Saddam Hussein, Robert Mugabe and Muammer Gaddafi? All these leaders caused unjustified suffering for their people. Olree (2005) rightly argues that:

[F]or this reason, Paul's statement should not be read to imply that every use of force by government is justifiable by definition. To say this would be to morally legitimatize the Holocaust, the Crusades, and the persecution of Christians in ancient Rome, all [of] which involved acts of force performed by governments. (p. 191)

In the third section, three verses lead to the climax of the discourse. In Verse 5, Paul raises another interesting issue of conscience. Subjects should submit to the authorities not out of fear of the wrath that comes with disobedience, but because of their conscience. Then he reaches the climax of his discourse by instructing Christians to pay their taxes and debts. What does he mean by the word 'conscience'? The word translated as 'conscience' is the accusative, singular,

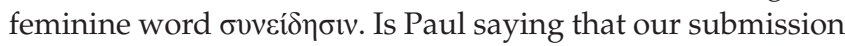
to the authorities should be guided by our conscience? Again, views differ on the interpretation of the meaning of this word in the Pauline context. Forell believes that Paul is referring here to our conscience. For example, he argues that it is unsafe to go against one's conscience, and Christians must not let their respect for authority make them into tools of injustice, oppression, and cruelty' (Forell 1975:29). So, Forell is against blind obedience and is advocating critical obedience. Such an understanding of conscience limits one's obedience because what is against conscience cannot be done. Moo (1996) defines conscience differently:

[I]t refers here to the believer's knowledge of God's will and purposes. The necessity for Christians to submit to government is, therefore, no mere practical expedient, a means of avoiding punishment. It arises ultimately from insight into God's providential ordering of human history. (p. 803)

Conscience here is not taken as independent from Paul's instructions; it is that positive aspect of seeing submission to the authorities as the right thing to do.

In verses 6 and 7, Paul concludes that Christians should pay their taxes and debts. Dunn proffers that 'tribute is the very climax of the discussion' (Dunn 1988:766). The issue of controversy surrounding the payment of tax remains a major challenge even today. Jesus spoke about these issues in Mark 12:17, Matthew 22:21b and Luke 20:25. For example, how can we continue to pay, as citizens, to a government that misuses public funds? How can we pay taxes in a context where they 
are used to sponsor terror on citizens? Again, Paul does not think of such scenarios, and we must understand him in own context, where these taxes were used not only to develop public infrastructure, but also to sponsor the emperor's lavish lifestyle. However, in a context where Christians were the minority, it was catastrophic for Christians not to abide with the statutes of the state because such a behaviour invited persecutions.

Contrary to the view that Romans $13: 1-7$ is an interpolation, a close reading revealed that it is part of the larger corpus, which starts from Chapter 12, though there is a lack of a conjunction in chapters 12 and 13. It has been established that the literary context plays a significant role in the analysis of the pericope. Paul is consistently addressing the issue of building new Christian identity boundaries based on love and doing what is good.

\section{Appropriation of Romans 13:1-7 to the new dispensation of the Second Republic of Zimbabwe}

What is appropriation? Is not all exegesis already appropriation? Bergmann argues that the 'appropriation of biblical texts means that the texts are applied outside of their original historical context to give insight to new issues' (Bergmann 2013:39). Here, the original historical context is the Roman Empire during the period of Paul, and the new issue is the conduct of the Second Republic of Zimbabwe. In the words of Rugwiji, 'to appropriate is to make what was alien become one's own' (Rugwiji 2020:1). Therefore, the Roman Empire of Paul's time is alien to us, but we are making it our own in the Second Republic. The Bible is an ancient document and written in a different context than ours; hence, we cannot appropriate it straightforwardly. What we need to do is to pick some thematic issues or theological issues as we appropriate it to our context. Heacock argues that 'this reality offers a new means of engagement both with the contemporary culture and the text' (Heacock 2016:4). West concurs with Heacock in that 'appropriation offers information on how the text was appropriated in different contexts and how it addressed social justice' (West 2013:3). As we appropriate Romans 13:1-7 to the Second Republic, there is a need to examine how the text addresses issues of social justice for us.

\section{Firstly, in Parsons (1940) St Augustine argues that:}

Christian liberty does not exempt man from obedience to his temporal rulers. We must be subject to the powers; that is, to the men who administer human affairs with some position. (p. 329)

As Zimbabwean Christians, we should obey our governments, but that obedience should be in the context of commands and policies that are constitutional. For example, we have to pay taxes, levies and other financial obligations that are required by the government in line with the constitution. These taxes are used to develop the country and provide public service to the citizens. However, it is the right of citizens to demand accountability for the use of these public levied funds. The government is necessary in bringing order to the society; otherwise, without governments, nations would be uninhabitable. It is in this context that Paul talks of governments as ordained by God. Therefore, we should separate the divine institution of governments and the abuse of power by some of them. So what do we do in the context of governments that are abusing their power?

\section{Secondly, Forell (1975) argues that:}

$[W]$ hen Paul assures his readers that 'rulers are not a terror to good conduct, but too [sic] bad', he is thinking of a government which upholds the law in a fair and just manner. (p. 29)

\section{St Augustine in Parsons (1940) argues that:}

$[W]$ e must not be subject to any man who wishes to overturn in us that which God gave us for eternal life. Faith and morals are not subject to secular government. People must not obey evil commands. (pp. 330-332)

Our measure of obedience is determined by the government's compliance with the constitution of the country. This is our measure of a government that is not a terror to good conduct. Is this the case with the Second Republic? The truth of the matter is that governments differ, and this proposition might not apply to other governments. For example, in Revelations 13:7 the Roman government is described as 'the beast of the sea'. In Acts 5:29, the apostles refuse to submit to their governing authorities. The Second Republic, since its inception, is on record as having committed human rights abuses to the extent of killing lawful protesters. Chapter 4:59 of the constitution of Zimbabwe allows for the freedom to demonstrate and petition. Therefore, shooting demonstrators is a serious infringement of the country's supreme law (constitution). The Second Republic is on record as having abducted innocent citizens for standing for the truth; a good example is Dr Peter Magombeyi, who was abducted for speaking out for the rights of doctors. When the surgeon Dr Mbuwayesango led a demonstration of doctors to petition the government to provide information on the whereabouts of Dr Magombeyi, he was fired from his University of Zimbabwe job, only to be reinstated some few days later. Again, this is contravening the country's constitution. It has been proven that the Second Republic, just like the First Republic, has a culture of unleashing terror on people to enforce good conduct simply because they are a threat to their power. Therefore, Paul's proposition that 'rulers are not a terror to good conduct, but to bad' cannot apply to the Second Republic. That means that this statement cannot be applied literally to the context of the Second Republic. Furthermore, Morris argues that 'rulers may misuse the authority God has given them, but Paul's point is that that does not alter the fact that it was God who gave it to them' (Morris 1988:459). I agree with Morris, but the problem is that Paul seems to promote quietism in light of oppression. Then can we condemn Karl Marx when he viewed religion as the opium of the people? Is there wisdom in Paul's quietist philosophy? Dunn argues that 'Paul again draws here on the sound political wisdom of an Israel tested by oppression and dispersion to counsel a policy on political quietism' 
(Dunn 1988:759). Paul's point is that it is not wise for subjects to displease the governing authorities because they have powers to punish. The word 'sword', therefore, means 'capital or corporal punishment'. A mirror of verses 3 and 4 on the part of the governing authorities may save us an exhortation to them to exercise justice. The subject of whether the Second Republic is ordained by God or not remains debatable. President Mnangagwa's mantra that the voice of the people is the voice of God' justified God's involvement through the people in the establishment of the Second Republic. The participation of the people in the November 2017 demonstration that finally forced Mugabe to resign is seen by Mnangagwa as the voice of God and the endorsement of the Second Republic. From Mnangagwa's perspective, the people should therefore submit to this God-ordained republic.

How is that justified in light of the suffering of the masses as a result of dirty politics by the Second Republic? Therefore, submission to the authorities should not be taken as a dose on contemporary church-state relations but as Paul's approach in addressing the challenges of his time. The text should therefore be read in its rightful context; then its appropriation depends on the context. Paul was a man of his own time and his theology cannot be applied to the contemporary context without interrogating the original context. This means that Zimbabwean Christians have the right to challenge the Second Republic by constitutional means such as demonstrations, petitions, public debates and ultimately through elections. However, they cannot use violent means because they are not within the confines of the constitution. Christians are therefore supposed to participate in the public space by engaging brutal governments as the voice of God calling for justice and love.

In conclusion, the community should first of all understand the will of God and then examine whether the governing authorities are complying with that will. The community should examine whether the governing authorities are terrorising the citizens into having good conduct. This is not an easy task because it is difficult for Christian communities to agree on what the will of God is. This means that when appropriating Romans 13:1-7 to the Second Republic, it depends on whether the governing is in line with the will of God. This proposition, then, does not prohibit people from resisting illegitimate and brutal governments, and the Second Republic is not spared. Therefore, Romans 13:1-7 should not be taken as a text canonising the unlawful and brutal acts of the Second Republic. The text should not be taken as promoting blind obedience and non-participatory citizenship on political, economic and social issues. On the contrary, the text allows for scrutinising the conduct of the governing and resisting whatever is ungodly.

\section{Acknowledgements Competing interests}

The author declares that he has no financial or personal relationships that may have inappropriately influenced him in writing this research article.

\section{Author's contributions}

I.S.G. is the sole author of this research article.

\section{Ethical considerations}

This article followed all ethical standards for research without direct contact with human or animal subjects.

\section{Funding information}

This research received no specific grant from any funding agency in the public, commercial or not-for-profit sectors.

\section{Data availability}

Data sharing is not applicable to this article as no new data were created or analysed in this study.

\section{Disclaimer}

The views and opinions expressed in this article are those of the author and do not necessarily reflect the official policy or position of any affiliated agency of the author.

\section{References}

Bergmann, N.W., 2013, 'Ecological appropriation of Joel', Australian eJournal of Theology 20(1), 34-48. https://espace.library.uq.edu.au/data/UQ_299430/UQ299430.

Boehme, R. (ed.), 2018, '2018 Report on International Religious Freedom', US Department to State, Washington, DC.

Bratton, M. \& Masunungure, E.V., 2018, Heal the beloved country: Zimbabwe's polarized electorate, Afrobarometer Policy Paper No. 49, viewed 23 March 2020 from https://media.africaportal.org/documents/ab r7 policypaperno49 heal the_beloved_country_zimbabwes_polarized_electorate.pdf.

Brenda, T., 2011, 'Rome, rulers and respect: The historical context of romans 13', Shaper iron, viewed 20 March 2020, from https://sharperiron.org/article/romerulers-and-respect-historical-context-of-romans-13.

Brett, E.A., 2006, State failure and success in Uganda and Zimbabwe: The logic of political decay and reconstruction in Africa, Working Paper No. 78, viewed 24 political decay and reconstruction in Africa, Working Paper No. 78, viewed 24
March 2020, from https://www.tandfonline.com/doi/abs/10.1080/0022038070 1848350.

Chitiyo, K. \& Kibble, S., 2014, Zimbabwe's international re-engagement the long haul to recovery, Chatham House Report, The Royal Institute of International Affairs, London.

Culpepper, A.R., 1974, 'God's righteousness in the life of his people: Romans 12-15,' Review and Expositor 73, 4. 451-463. https://doi.org/10.1177/003463737607300407

Dunn, J.D.G., 1988, Romans 9-16, vol. 38B, Word Biblical Commentary, Word Books Publisher, Dallas, TX.

Esler, P.F., 2003, Conflict and identity in Romans: The social setting of Paul's letter, Fortress Press, Minneapolis, MN

Forell, G.W., 1975, The Christian lifestyle: Reflections on Romans 12-15, Fortress Press, Philadelphia, PA.

Garlake, P., 1973, Great Zimbabwe: New aspects of archaeology, Thames and Hudson, London.

Gorman, M.J., 2009, Elements of biblical exegesis, rev. edn., Baker Academic, Grand Rapids, Ml.

Gusha, I.S., 2019, 'Memories of Gukurahundi massacre and the challenge of reconciliation', Studia Historiae Ecclesiasticae 45(1), 1-14. https://upjournals. co.za/index.php/SHE.

Heacock, C., 2016, 'Biblical literacy: Cultural appropriations of the scripture and the potential impact upon preaching', Academia, viewed 28 March 2020, from https:// www.academia.edu/15300660/Biblical_Literacy_Cultural_Appropriations_of_the Scriptures_and_the_Implications_for_Preaching.

Horrell, D.G., 2003, 'The peaceable, tolerant community and legitimate role of the state: Ethics and ethical dilemmas in romans 12:1-15:13', Review \& Expositor 100(1), 81-99.

Isaak, J.M., 2003, 'The Christian community and political responsibility: Romans 13:1-7', Direction 32(1), 32-46.

Kasemann, E., 1980, Commentary on Romans, Eerdmans, Grand Rapids, MI.

Kusio, M., 2015, 'Theological implications of markan interpretative intercalations', Ruch Biblijny i Liturgiczny 68(3), 265-288. https://doi.org/10.21906/rbl.21

Longenecker, R.N., 2016, The epistle to the Romans, NIGTC, William B. Eerdmans, Grand Rapids, MI. 
Marshall, J.W., 2008, 'Hybridity and reading romans 13', Journal for the Study of the New Testament 31(2), 157-178.

Matikiti, R., 2009, 'Church and state relations: The contribution of John Calvin to the understanding of church-state relationships in 21st century Zimbabwe', viewed 25 March 2020, from http://uir.unisa.ac.za/bitstream/handle/10500/4568/MatikitiSHEXXXV_2_- October2009.pdf?sequence $=1$.

McDonald, J.I.H., 1989, 'Romans 13:1-7: A text case for new testament interpretation' New Testament Studies 35, 540-549. https://doi.org/10.1017/S0028688500015204

Moo, D.J., 1996, The epistle to the Romans, NICNT, William B. Eerdmans, Grand Rapids, MI.

Morris, L., 1988, The epistle to the Romans, PNTC, William B. Eerdmans, Grand Rapids, MI.

Moulder, J., 2017, 'Romans 13 and conscientious disobedience', Journal of Theology for Southern Africa 21, 13-23.

Murisa, T., 2019, New dispensation? Bravado, incoherencies, and costly blunders, SIVIO Institute, Harare.

Nkomo, C., 2019, 'Setting the agenda: What are the key issues?', Journal of Alternatives for a Democratic Zimbabwe 1(28), 3-6.

Noyes, A.H., 2020, A new Zimbabwe? Assessing continuity and change after Mugabe, Rand Corporation, Santa Monica, CA.
Neufeld, M.G., 1994, 'Submission to governing authorities: A study of romans 13:1-7', Direction 23(2), 90-97.

The Zimbabwe Human Rights NGO Forum, 2019, The new deception: What has changed?, The Zimbabwe Human Rights NGO Forum, Harare.

Olree, A.G., 2005, 'Government as God's agent: A reconsideration of romans 12 and 13', Stone-Campbell Journal 8(2), 181-197.

O'Neill, J.C., 1975, Paul's letter to the romans, Harmondsworth, Penguin.

Parsons, W., 1940, 'The influence of romans XIII on Christian political thought II. Augustine to Hincmar', Theological Studies 1(4), 337-364. https://doi.org/ 10.1177/004056394000100401

Rugwiji, T., 2020, 'The quest for hermeneutics of appropriation as a thematic approach for critical biblical interpretation', HTS Teologiese Studies/Theological Studies 76(1), a5392. https://doi.org/10.4102/hts.v76i1.5392.

Thiselton, A., 2016, Discovering Romans: Content, interpretation, reception, William B Eerdmans Publishing Company, Grand Rapids, MI.

West, G., 2013, 'Exegesis seeking appropriation; appropriation seeking exegesis: Rereading 2 Samuel 13:1-22 in search of redemptive masculinities', Verbum et Ecclesia 34(2), 1-6. https://doi.org/10.4102/ve.v34i2.761

Zimbabwean Government, 2013, Constitution of Zimbabwe Amendment (No. 20) Act 2013, Government of Zimbabwe, Harare. 